\title{
Does Kosovo Lie in the Lotus-Land of Freedom?
}

\author{
ANNE PETERS*
}

\begin{abstract}
This paper finds that the ICJ's Kosovo Advisory Opinion reached the right result, but in a methodologically not fully satisfactory way. It examines five aspects that underpin the opinion: the temporal (purely ex post) perspective; the Court's equation of legal conformity and nonprohibition and the idea of a deliberate silence of international law; the applicability of the Lotus principle that was evoked by numerous states in the proceedings; the structural analogies between international law and private, criminal, or public law; and the oscillation between legal positivist and jusnaturalist paradigms. Finally, the paper argues in favour of procedural requirements for the international lawfulness of secession, and claims that this approach is compatible with the findings of the Advisory Opinion.
\end{abstract}

\section{Key words}

independence referendums; international law-free zone; Lotus principle; secession (remedial or preventive); territorial integrity

\section{The COURT's Advisory OpINION}

The Advisory Opinion of 22 July 20I0, Accordance with International Law of the Unilateral Declaration of Independence in Respect of Kosovo, gives a tripartite answer to the question, asked by the General Assembly: 'Is the unilateral declaration of independence by the Provisional Institutions of Self-Government of Kosovo in accordance with international law?' ${ }^{\text {I }}$ First, the declaration of independence 'did not violate general international law'. ${ }^{2}$ For the International Court of Justice (ICJ), no 'rule prohibiting the making of a declaration of independence'3 can be inferred, neither from state practice, ${ }^{4}$ nor from the practice of the Security Council. ${ }^{5}$ And because 'general international law contains no applicable prohibition of declarations of independence', there is no violation. ${ }^{6}$

\footnotetext{
* Prof. Dr. iur., LL M (Harvard), University of Basel, Switzerland [Anne.Peters@unibas.ch]. The author thanks Olivier Corten and Théodore Christakis for valuable criticism of previous versions of this text.

I Question reproduced in ICJ, Accordance with International Law of the Unilateral Declaration of Independence in Respect of Kosovo, Advisory Opinion of 22 July 2010, 2010 ICJ Rep., para. I (in the following: Kosovo AO).

2 Ibid., para. 84.

3 Ibid., para. 79.

4 Ibid., para. 79.

5 Ibid., para. 8I.

6 Ibid., para. 84: '[G]eneral international law contains no applicable prohibition on declarations of independence. Accordingly, ... the declaration of independence of I7 February 2008 did not violate general international law.'
} 
Second, the declaration 'did not violate Security Council Resolution I 244'.7 The Court could 'not accept the argument that Security Council Resolution I 244 (I999) contains a prohibition, binding on the authors of the declaration of independence [distinguished from the provisional authorities], against declaring independence [distinguished from secession]'. ${ }^{8}$ According to the Court, the resolution established 'an interim administration for Kosovo, without making any definitive determination on final status issues'. ${ }^{9}$

Third, the declaration did not violate the constitutional framework. ${ }^{\text {Io }}$ The reason is that the declaration of independence was not issued by the provisional institutions of self-government. Nor was it an act intended to take effect, or actually taking effect, within the legal order in which those provisional authorities operated. The authors of the declaration of independence were hence not bound by the constitutional framework and therefore could not violate it.

\section{THE COURT'S SIX DISTINCTIONS AND ONE EQUATION}

The ICJ managed to reach its conclusion by resorting to six fine distinctions, and one equation. First, it (implicitly) distinguished the declaration of independence from secession. Indeed, the question put to the Court referred to the declaration of independence. But what was really at stake was not the declaration as a speech act, but secession, which is the unilateral separation of a part of a state's territory and the formation of an independent, sovereign state on that territory. So, actually, the opinion is a legal assessment of secession.

Second, the Court distinguished 'different legal orders' (para. I 2 I): that of general international law, of the Security Council Resolution I 244, and of the constitutional framework. This allowed the ICJ to divide its answer into three parts.

Third, the World Court distinguished the merely interim legal solution (as created by Security Council Resolution I244) from a final solution (as envisaged by the authors of the declaration of independence). The Court deemed these two texts to 'operate on different levels' (para. I I4). This distinction was an important building block for the conclusion that the declaration of independence did not violate Resolution I244.

Fourth, the Court distinguished between the addressees of Security Council Resolution I244 and the authors of the declaration. The Security Council Resolution addressed mainly the United Nations and its organs, but not - according to the Court - the authorities of Kosovo (para. I I5). Again, this distinction allowed the Court to conclude that the declaration of independence did not violate Resolution I244, simply because the Resolution did not address those actors.

To the same end, the ICJ, fifth, if only implicitly, distinguished the provisional institutions (established by and acting within the constitutional framework) from

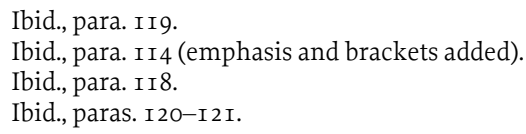


the authors of the declaration of independence who acted as a pouvoir constituant (not in legal continuity, and in a revolutionary break with the existing legal framework). ${ }^{\text {II }}$

Sixth, the Court stressed that the question whether the declaration of independence was 'in accordance with' international law was not the same as asking whether a positive entitlement or a 'right' to secede existed. ${ }^{12}$ 'Indeed,' said the Court, 'it is entirely possible for a particular act - such as a unilateral declaration of independence - not to be in violation of international law without necessarily constituting the exercise of a right conferred by it.' ${ }^{\text {'3 }}$

After drawing all those distinctions, the Court omitted one. It did not make a difference between 'being in accordance with' international law and not being prohibited. On the contrary, the ICJ stated that the declaration of independence was in accordance with international law if it was not prohibited: '[T]he General Assembly has asked whether the declaration of independence was "in accordance with" international law. The answer to that question turns on whether or not the applicable international law prohibited the declaration of independence.' ${ }^{\text {'4 }}$ Specifically with regard to the conformity of the declaration of independence with Resolution I244, the Court formulated its answer to the question along that line: it found that Security Council Resolution I244 does not contain a prohibition on declaring independence. ${ }^{15}$

Also, the Court treated as identical the question of whether an act was 'in accordance with' international law and the question of whether it did not violate the law, ${ }^{16}$ or - synonymously - the issue of 'the lawfulness of declarations of independence.. ${ }^{17}$ Although the question posed by the General Assembly was whether the declaration of independence was 'in accordance' with international law, the Court only once (besides when repeating the question posed) actively and operatively used this phrase. ${ }^{18}$ Nowhere does it explicitly state that the declaration was indeed in accordance with international law. Instead, the Court found that it was 'not in violation' of the law, or 'did not violate' it. ${ }^{\text {I9 }}$

\footnotetext{
I I Ibid., paras. I02-IO9.

I 2 The ICJ contrasted the question laid before it with the one posed to the Canadian Supreme Court in I998. In that case, the question was whether there was a 'right to effect secession of Quebec from Canada'.

I3 ICJ, Kosovo AO, para. 56.

I4 Ibid.

I5 ICJ, Kosovo AO, para. II8: '[T]he Court cannot accept the argument that Security Council resolution I 244 (I999) contains a prohibition.'

I6 The treatment as identical issues is most visible in the headings before paras. Ior and I Io. The heading 2 is 'The question whether the declaration of independence is in accordance with Security Council resolution I244 (I999) and the measures adopted thereunder'. Subheading (b) then is 'The question whether the authors of the declaration of independence acted in violation of Security Council resolution I 244 (I999) or the measures adopted thereunder'.

I7 The treatment of conformity and lawfulness as synonymous is visible in heading IV, 'The Question Whether the Declaration of Independence Is in Accordance with International Law' (before para. 78), and in para. 78 itself, asking for the 'lawfulness'.

I8 ICJ, Kosovo AO, para. 56.

I9 ICJ, Kosovo AO, paras. 84, I I9, I 20, I2 I, and I 22.
} 


\section{Five Underlying assumptions}

Various legal answers to a claim for independence or secession are conceivable. International law might prohibit it. Or international law might, on the contrary, embody a right to secede, or an allowance. It might tolerate, justify, or exculpate a secession. But international law might also be silent, with secession lying in an internationallaw-free zone. The 20Io Advisory Opinion gave one answer to secession, and it is the objective of this comment to uncover the underlying assumptions.

The international lawyers' response to secession depends on whether lawyers look at a declaration of independence (or at secession) ex ante or ex post on whether they apply a strictly binary logic or a nuanced one; on whether they espouse a residual rule of (state) freedom or not, from which lawyers of other legal fields (private, criminal, or public law) borrow structural elements; and, finally, on the theoretical paradigm favoured (whether a natural-law approach or a legal-positivist one). I will discuss these five assumptions one by one.

\section{I. Timing: ex ante or ex post}

The legal answer to the question of the legal admissibility of secession depends on the moment in which the question is asked, and of whom. For a legal adviser counselling political actors seeking secession beforehand, the crucial question is that of a 'right'. After the fact, for example in a judicial proceeding, the question may equally well be formulated as one of a toleration. A judge does not necessarily have to determine whether there was a right to effect the secession; it would suffice to find that it is ex post facto admissible.

However, it is one of the core functions of (international) law to be prescriptive, to give normative guidance to actors in advance. Therefore, the ex ante perspective is an important one. It is not in functional terms sufficient to determine the law on the basis of mere 'normative ripples' after the fact. Hence, the question of a right to secession should not be discarded as being unimportant. In the ex ante perspective, the alternative to a right might be a mere privilege. International law embodies if not a right, possibly a privilege to secede. The Court did not examine the question of a right to secede, because it was not explicitly asked to do so. ${ }^{20}$ It would have been possible to give a broader answer to the question posed, but a broad response, besides being unable to gain consensus in the Court, would have surely provoked criticism of judicial activism. The Court probably had no choice in letting pass an opportunity to clarify a crucial question of international law.

\subsection{Binarism and silence of the law}

The Court equated, as mentioned above, conformity (accordance) with international law with non-prohibition. It also equated conformity with non-violation. However, legal rules do not only follow the binary logic of 'prohibited' or 'allowed' (or of violation versus non-violation).

20 Ibid., paras. 55-56 and 83. 
The very fact that the Court chose to phrase its answer in terms of 'non-violation' (as opposed to 'being in accordance with') underscores the existence of a subtle difference between those two verdicts. While the assessment of an act as being 'in accordance with' the law has a positive and approving connotation, qualifying a behaviour as a mere non-violation rather implies some disapproval. It is surely no pure coincidence that the Court chose the rather disapproving term, instead of employing the wording of the question placed before it.

The nuances of the law could have been made clearer by the Court. The ICJ could have acknowledged that besides setting up prohibitions and permissions, the law might follow a middle course, and espouse an intermediate attitude towards certain behaviour. There may be a range of 'non-prohibited options', as Judge Simma (who otherwise voted with the majority) put it in his declaration added to the opinion..$^{21}$ International law might embody recommendations, guidelines, or presumptions. In the context of secession, it seems likely that international law establishes a presumption against the admissibility of secession, because it favours stability. The majority's focus on non-violation seems to imply this, but fails to articulate it.

The fact that the Court was not able to identify an international (prohibitive or permissive) rule on secession does not inevitably warrant the conclusion that there is an (international) law-free zone in that regard. As Judge Simma highlighted in his declaration, there might also be a deliberate silence of (international) law. ${ }^{22}$ Deliberate silence is the opposite of a legal lacuna. Deliberate silence of the international lawmakers means that secession remains prohibited - or allowed, depending on what one take's as the residual rule. Assuming that the residual rule is the rule of state stability, ${ }^{23}$ a deliberate silence of international law implies a prohibition of secession.

However, the idea of deliberate silence, well known in domestic law, does not fully fit into the structure of international law. In the domestic (democratic) sphere, the lawmaker normally is parliament. Bills are publicly debated, and the reasons for adopting or not adopting it become apparent in these public debates. Motives and reasoning can in hindsight be relatively easily identified by consulting the public records. In contrast, in the international sphere, there is no central lawmaker, and the debates leading to the formulation of treaties take place behind closed doors. It is much more difficult to identify the lawmakers' intent behind international non-regulation. Overall, the structure of the international legal process rather leads to unwanted or unconscious non-regulation (as opposed to deliberate or conscious non-regulation). And, finally, the conclusion to draw from deliberate silence depends on the prior establishment of the residual rule (freedom to secede or preservation of the state). In the end, the speculation that international law-producers might have been deliberately silent on secession does help much in finding the legal answer to secession.

\footnotetext{
2 I Ibid., Declaration of Judge Simma, para. 9.

22 Ibid.

23 For the reasons stated in subsection 3.4 below.
} 


\subsection{Lotus}

By saying that the declaration of independence is in accordance with international law because it was not prohibited, the Court might have implicitly relied on the Lotus principle. In the Lotus judgment, the Permanent Court of International Justice (PCIJ) had highlighted that the 'rules of law binding upon States ... emanate from their own free will .... Restrictions upon the independence of States cannot therefore be presumed'. 'Far from laying down a general prohibition ...., it [international law] leaves them in this respect a wide measure of discretion which is only limited in certain cases by prohibitive rules. ${ }^{24}$

States that supported the independence of Kosovo referred to the Lotus principle in their written statements $\mathrm{s}^{25}$ and pleadings, ${ }^{26}$ whereas Serbia took pains to demonstrate that the Lotus principle had no room in the case of Kosovo. ${ }^{27}$ Also, the Court itself did not cite the Lotus judgment.

I think that Serbia is right, and that the Court was well guided not to cite Lotus. The basic idea of Lotus is that what is not prohibited is allowed - for states. The principle thus encapsulates a presumption of (state) freedom. In the Kosovo case, this residual rule of freedom was not applied to the state, but to the authors of the declaration of independence. The absence of a prohibition did not work in favour of the 'mother state', but against that state. Applying the residual rule of freedom to a non-state entity actually reversed the Lotus postulate. It would have been strange to call this reversal an application of the principle.

On the other hand, the Court's (implicit and reversed) resort to Lotus is consistent with its finding with regard to the role of the authors of the declaration of independence. The traditional presumption of freedom as encapsulated in Lotus is a corollary of state sovereignty and the traditional idea of a state's a priori unlimited regulatory competence (Allzuständigkeit). ${ }^{28}$ This is inapplicable to the provisional institutions of self-government of Kosovo. These derive their authority and their concrete competences from Resolution I 244 and therefore from the UN Security Council. ${ }^{29}$ These institutions enjoy only those limited powers that have been accorded to them by that resolution (competences d'attribution), and under the oversight of the special representative of the Secretary-General. By (implicitly) applying the Lotus principle in favour of the authors of the declaration of independence, the Court confirms that they have not acted in their role as provisional institutions deriving their powers from Resolution I244, but as revolutionaries, in normative discontinuity to the pre-existing legal framework. ${ }^{30}$

PCIJ, SS Lotus Case (France v. Turkey), PCIJ Rep., (I927) Series A No. Io, at I8-I9.

Austria, written statement of I6 April 2010, paras. 22-23; Denmark, written statement of I7 April 20Io, ses. 2.2., at 3 .

Germany, pleadings (Wasum-Rainer), CR 2009/26 of 2 December 2009, para. 22 (at 29); Croatia, pleadings (Andreja Metelko-Zgombić), CR 2009/29 of 7 December 2009, at 52; Denmark, pleadings (Thomas Winkler), CR 2009/29 of 7 December 2009, at 69.

Serbia, written statement of 17 April 2010, paras. I0I7-I032, at 350-6.

I leave aside the problem that under the (both national and international) rule of law, this idea has become untenable.

ICJ, Kosovo AO, para. 89.

Ibid., para. I05. 
The idea that everything that is not prohibited is allowed does not necessarily imply that the international legal order is complete. The allowance may be explained in two totally different ways. It may be either the result of a residual legal rule (of freedom), or it may, in contrast, be the result of a legal lacuna. The PCIJ's Lotus judgment therefore did not unequivocally espouse a legal-positivist approach. The residual rule of freedom established in that judgment is rather inspired by a jusnaturalist idea: states are free because they are in the state of nature.

Concomitantly, the Kosovo Court's implicit and upside-down Lotus approach does not take sides with the traditional idea that secession happens in an internationallaw-free zone. ${ }^{3 \mathrm{I}}$ The Kosovo AO can be read both ways: either secession is outside international law in the sense that international law is simply neutral vis-à-vis secession, or international law allows secession. To conclude, Lotus is not the key to Kosovo.

\subsection{Structural analogies: private, criminal, or public law}

Although it has been said that international law is neither private nor public, but simply international, it is a fact that international lawyers borrow building blocks for legal reasoning from domestic law, which has formed their basic legal training. This fact need not be deplored, because, after all, international law has evolved exactly through this type of reasoning and does not exist in an intellectual vacuum. The view on secession much depends on where we borrow structural elements from, and whether we (consciously or not) perceive international law as being structured like private law, public law, or criminal law. ${ }^{32}$

At the end of the nineteenth century, international law was famously called 'private law writ large. ${ }^{33}$ Seen that way, states are analogous to natural persons in the state of nature. They are sitting on a horizontal plane, and enjoy 'fundamental rights'. Therefore, a presumption of freedom (of states) reigns. This view dovetails with the Lotus principle as explained above.

But international law has also, second, received some structural elements from criminal law. Where secession is depicted as a means of last resort, as the ultima ratio in a 'state of necessity', the debate is conducted within this criminal-law paradigm. Just as self-defence under Article 5I of the UN Charter is a justification for the resort to military force that would otherwise violate Article 2(4), secession might be construed as a 'defence'. It might be a justification or exculpation of an otherwise illegal act. This construction of course works only on the premiss that secession does not occur within an international-law-free zone. If secession were not regulated by international law at all, then it would not constitute a breach of an international

3I The idea that secession is neither allowed nor prohibited by international law is widespread. Its principal justification is that the principle of territorial integrity is directed at the outside, at third states. The Kosovo AO espouses this view: 'Thus, the scope of the principle of territorial integrity is confined to the sphere of relations between States' (para. 80). But this statement seems hardly in conformity with recent practice of states and international organizations. See, on that issue, Olivier Corten, in this issue.

32 See in more detail A. Peters, 'Transnational Law Comprises Constitutional, Administrative, Criminal, and Quasi-private Law', in P. Bekker (ed.), Making Transnational Law Work: Liber Amicorum Detlev Vagts (2010), I54-73.

33 T. Holland, Studies in International Law (1898), I 52. 
obligation in the first place. In international law, the difference between these two types of defence (removal of wrongfulness or removal of guilt) has so far not been clearly worked out, last but not least because the concept of guilt can not easily be applied to a moral person such as a state.

In the international law of state responsibility, the defences in the ILC Articles on state responsibility are called 'circumstances precluding wrongfulness', but some of them describe situations that merely remove culpa, such as some forms of necessity. ${ }^{34}$ In any case, the idea of exculpation is a gateway for introducing moral arguments into the debate on secession.

Third, modern international law displays many features of public law, ${ }^{35}$ as expressed by the label 'public international law'/'droit international public'. The entire process of what has been called the constitutionalization of international law ${ }^{36}$ might be characterized as a move from private to public law: from horizontal to more vertical (hierarchical) relations, from treaty-making to law-making, from bilateral state interests to community interests.

In the public-law analogy, large parts of international law can be viewed as regulatory. Respect for territorial integrity appears as a kind of preventive prohibition. A dangerous activity such as a proclamation of independence would then need a licence or permit.

Most importantly, public law is characterized by a specific technique of deciding conflicts, namely balancing. The balancing technique is a consequence of the fact that public law is to a large extent made up of principles as opposed to rules. Principles are not all-or-nothing norms, but call for optimization. They can be implemented to a greater or lesser extent. This also means that a conflict of principles (e.g. of the fundamental right of privacy versus freedom of the press) must not be solved by an all-or-nothing decision, but through optimization and reconciliation.

Balancing requires the jurist to assess the importance of the conflicting legally protected interests and to strike a fair balance according to their respective weight. One of the objectives of balancing is to reconcile these interests to the largest extent possible by defining a compromise solution.

The balancing technique is closely associated with the principle of proportionality, that stems from administrative and constitutional law. In domestic public law, the principle of proportionality requires authorities and courts to curtail the freedom of the citizens only to the least extent necessary.

Seen through the lens of public law, territorial integrity and self-determination are conflicting legal principles. The conflict must be solved by balancing. In the balance-image, the balance seems to be tilted towards territorial integrity. Because all territorial boundaries are more or less the product of injustice and fortune, and because a rational and fair determination of new boundaries seems in normative and

See generally T. Christakis, 'Les “circonstances excluant l'illicéité”: une illusion optique?', in T. Christakis, Droit du pouvoir, pouvoir du droit: Mélanges offerts à Jean Salmon (2007), 223-70, finding that most of the circumstances enumerated in the ILC Articles do not exlude illegality, but rather exclude or only temper responsibility.

35 See in this sense also ICJ, Kosovo AO, declaration of Judge Simma, para. 3.

36 A. Peters, J. Klabbers and G. Ulfstein, The Constitutionalization of International Law (2009). 
practical terms impossible, there is a presumption that the maintenance of the territorial status quo best serves peace and human security. Still, if very weighty factors support the realization of the claim to self-determination in its most extreme form, which is secession, the balance may tip against the preservation of the territorial integrity of the state. This might be warranted when massive discrimination and other human rights violations are taking place, and when internal self-determination has been persistently denied.

With regard to Kosovo, the objection is that the discrimination, persecution, killing, and marginalization of Kosovars, as documented by human rights organizations and in the ICTY judgment Milutinovic, 37 happened years ago. Therefore the grounds for allowing a remedial secession of Kosovo have no longer been present. Moreover, discrimination of Serbs and Roma by Kosovars abounds.

However, the facts that constituted a ground for justifying remedial secession of Kosovo were probably only removed through the establishment of the international administration. But this administration could not go on for ever. A reversal of the territory to Serbia, in the absence of a policy change by Serbia, would have offered Serbian authorities the opportunity to commit discriminatory acts against Kosovars and again deny their right to meaningful political participation. It is difficult to estimate the likelihood of such a scenario, and impossible to predict whether a future of Kosovo within Serbia would again amount to a denial of the right to internal self-determination of the Kosovar people. So, although it can well be argued that grounds for a secession are still present, but merely dormant, this statement is in scientific terms improvable, but remains a policy assessment. Secession would not be 'remedial', but rather 'preventive'. In such a case, the legal presumption in favour of the maintenance of the territorial integrity might come into play. If such a presumption formed part of international law as it stands (which is unclear), the reasoning would, contrary to the Court, lead to the conclusion that secession was not in accordance with international law.

But is borrowing structural elements from public law appropriate with regard to the question of secession and statehood? Domestic public law regulates hierarchal relationships between authorities and citizens. Under the international legal principle of sovereign equality, the relationships between states are not governed by legal hierarchy. Moreover, there is no central recognition authority. Quite to the contrary, the horizontal and decentralized character of international law is particularly obvious when it comes to the qualification of a territorial entity as a state, which is performed by each other state on its own. For sure, the decentralized institutional form of the international legal order does not prevent resort to the balancing technique. Balancing seems to be the most appropriate approach to resolve conflicts between legal goods that are not ranked in a normative hierarchy. But the non-hierarchical relationship of the legal goods at stake is a different issue from the non-hierarchical institutional set-up. It crucially matters who does the balancing.

37 Cf. Prosecutor v. Milan Milutinović, judgement of the trial chamber of 26 February 2009, finding mass killings and sexual assaults motivated by ethnic hatred, and the destruction of religious sites, committed by Serbs against Kosovars, ICTY, IT-05-87 T. 
With regard to Kosovo, the International Court of Justice should have seized the opportunity to do it.

\subsection{Paradigms: from legal positivism to natural law}

Finally, the assessment of secession hinges on the overall paradigm within which the international lawyer reasons. A consistently legal-positivist outlook would have to support the idea that secession is not regulated by international law, for two reasons. First, from a legal-positivist perspective, which strictly separates the 'is' from the 'ought' and places a premium on factual power (auctoritas, non veritas facit legem ${ }^{38}$ ), a state is a matter of fact, a fait primaire. ${ }^{39}$ It is from that perspective logical that the events leading to the formation of a state are only 'facts' as well, and are not regulated by international law.

Second, a legal-positivist vision of international legal order implies that this order consists only of what is written or what exists as a clear customary rule. The international legal order is complete (without lacunae). Secession is from that perspective not based on any higher law, but simply lies in the realm of (contested) morality, viewed as strictly separate from the realm of international law. ${ }^{40}$

In contrast, natural-law-followers, if they want to be consistent, should look favourably at secession. Generally speaking, naturalists have a larger vision of what constitutes the legal order. They assume that not all law is codified and laid down positively, and accept natural law 'above' positive law. From that perspective, a remedial right to secession constitutes a kind of higher law. It is reminiscent of the classical natural right to resistance against the tyrant. As an ultima ratio, resort to this higher principle is allowed.

As explained above, the Kosovo AO's reliance on the absence of a legal prohibition on making a declaration of independence does not allow any firm conclusion on the favourite paradigm of the majority.$^{4 \mathrm{I}}$ I submit that with regard to the specific question of secession, a legal strictly positivist approach relying exclusively on statemade sources is particularly problematic. It is futile to look for positive international legal rules on the achievement of statehood through secession. The search is vain because in the current framework of legal sources, these rules are inevitably statemade. This is true for treaties, custom, and general principles. In the field of secession, a customary law rule would be needed. But such a customary rule could only emerge out of the practice and opinio juris of states. It is most unlikely that states themselves will create a rule that threatens their proper existence. Relying on such a rule amounts to making the fox guard the hen house.

International lawyers therefore only have two options: they must either acknowledge that there will never be a hard and fast international rule allowing for or

38 T. Hobbes, A Dialogue between a Philosopher and a Student of the Common Laws of England (I 68I), ed. by J. Crosey (I97 I), at 55: 'It is not Wisdom, but Authority that makes a Law.'

39 G. Abi-Saab, Cours général de droit international public (I987/VII) 207 Recueil des cours de l'Académie de la Haye 9 , at 68 .

40 Note that there is not only a choice between law and morality to make. Even if there is no rule on secession in international law, the issue may still be regulated by domestic law.

4I See above, Subsection 3.3. In contrast, Judge Cançado Trindade's separate opinion displayed some affinity with a jusnaturalist approach. 
tolerating secession, or resort to a legal source outside the state-made sources. The structural insufficiency of treaties and custom in that particular issue, namely secession, justifies relying on a subsidiary source of international law. As stated in Article 38, paragraph I(d) of the ICJ Statute, 'the teachings of the most highly qualified publicists of the various nations' may be taken into account when looking for a legal answer to secession. ${ }^{42}$ It is therefore relevant that the concept of 'remedial secession' enjoys widespread support in international legal scholarship. ${ }^{43}$ The Court's outcome was in line with that important scholarly strand. It could have relied on those 'teachings of publicists' to support its finding, but this seemed to have been given the deep rifts among the judges - in practical terms impossible. ${ }^{44}$

\section{Procedural Requirements for secession}

A merit of the Kosovo AO is its distinction between the objective of secession and the means to reach it. As stated above, the absence of an international legal prohibition on the making of a declaration of independence led the Court to conclude that such a declaration (and the secession effected by it) was not in violation of international law. However, and this is important, not all means to achieve this end are allowed. The Court stated that 'the illegality attached to [certain] declarations of independence ... stemmed ... from the fact that they were, or would have been, connected to the unlawful use of force'. A secession may be illegal if realized through use of force or through 'other egregious violations of norms of general international law, in particular those of a peremptory character (jus cogens)'. ${ }^{45}$ So the Kosovo Court said that the use of force is prohibited in secession processes, but did not say whether the international prohibition of the use of force is applicable within the territory of a not yet definitely dissolved state, and to whom this prohibition is addressed.

42 Incidentally, the PCIJ in Lotus mentioned the 'teachings of publicists', but left expressly apart 'the question as to what their value may be from the point of view of establishing the existence of a rule of customary law'. PCIJ, SS Lotus Case (France v. Turkey), supra note 24, at 26.

43 Diagnosing and supporting remedial secession (as a rule of positive international law derived from the savings clause of the Friendly Relations Declaration), C. Tomuschat, 'Secession and Self-determination', in M. Kohen (ed.), Secession: International Law Perspectives (2006), 23, at 42: '[R]emedial secession should be acknowledged as part and parcel of positive law, notwithstanding the fact that its empirical basis is fairly thin. But not totally lacking.' See also T. Schweisfurth, Völkerrecht (2006), at 382; M. Suksi, 'Keeping the Lid on the Secession Kettle: A Review of Legal Interpretations Concerning Claims of Self-Determination by Minority Populations', (2005) I 2 IJMGR I 89, at 225: 'Unilateral secession from an existing State is not supported by public international law except in some very special circumstances that, against the background of the solutions in situations like Kosovo and Chechnya, are almost unlikely to materialise' (emphasis added). See the wealth of references to numerous eminent authorities, including Karl Doehring, Yoram Dinstein, Hurst Hannum, P. H. Kooijmans, Daniel Thürer, and Luzius Wildhaber, in A. Tancredi, 'A Normative "Due Process" in the Creation of States through Secession', in Kohen (ed.), supra, at I75, note I3.

44 In their entire history, the PCIJ and the ICJ have extremely rarely, and only summarily, referred to teachings, doctrine, or the opinion of writers (see the references in A. Pellet, 'Article 38', in A. Zimmermann et al. (eds.), The Statute of the International Court of Justice (2006), 677, at 79I, para. 32I). This does not mean that legal doctrine is not being taken into account. The lack of explicit references rather indicates that the Court prefers not to base its authority on scholarly writing, or it might simply show that the Court (or the majority of the judges) does not find existing scholarship sufficiently convincing. Both could have been the case in the Kosovo advisory proceeding. Clear support for remedial secession was expressed only by Judge Yusuf, sep. opinion, paras. I I-I6.

ICJ, Kosovo AO, para. 8I. 
As for the addressees of the prohibition, three types of actor come to mind: third states, the 'mother state', or the secessionist groups. Article 2(4) of the UN Charter itself only binds states (as opposed to non-state actors), and applies only in 'international relations'. The Court gave examples for declarations of independence that were tainted by the illegal use of force, and were condemned by the Security Council. In those cases, third states used force: Turkey with regard to the Turkish Republic of Northern Cyprus, and Serbia with regard to the Republika Srpska. However, in those cases, not only third states, but also the 'mother state' and the secessionist forces resorted to military violence. Paragraph 8I of the Kosovo AO leaves open whether their action is covered by the prohibition of the use of force as well. While the Court, in paragraph 80 of the Opinion, quoted Article 2(4) of the Charter and stated that 'the scope of the principle of territorial integrity is confined to the sphere of relations between states', it did not make that statement with regard to the principle of non-use of force. Although both principles (territorial integrity and non-use of force) are enshrined on one provision of the Charter, they are not identical in contents. The principle of territorial integrity protects states, whereas - in a humanized international order - the prohibition of the use of force primarily protects human beings. Non-use of force is jus cogens, whereas territorial integrity is not. Given the different substance and normative status of those two principles, their addressees might differ as well.

So, are secessionist non-state actors bound by the prohibition of the use of force? Article 2(4) of the Charter, explicitly addressed to 'members' of the UN, does not bind them. Their obligation to refrain from the use of force could only stem from a broader customary rule (or from treaty arrangements, such as ceasefire agreements). The Kosovo Court's dictum in paragraph 8I seems to imply the existence of a customary rule that has moreover the quality of jus cogens, as the Court highlights. If the non-useof-force rule's peremptory quality is decisive, then this rule must be respected by the central government, representing the 'mother state', as well.

The follow-up question is then whether this also applies within the territory of that state. The Kosovo Court's statement contains a positive answer, because the situation of a unilateral declaration of independence 'connected with the unlawful use of force'46 invariably is within the 'mother state'. Thus, the Court implied that the prohibition of use of force may (under special circumstances) be applicable in the interior of a state territory, in a conflict between a secessionist movement and the central government. This is in line with a doctrinal strand asserting that so-called stabilized defacto regimes are bound by the prohibition of the use of force, ${ }^{47}$ and finds

46 Ibid.

47 J. A. Frowein, 'De facto Regime', Max Planck Encyclopaedia of Public International Law (www.mpepil.com), paras. 4-5; A. Randelzhofer, in B. Simma (ed.), The Charter of the United Nations: A Commentary (2002), Vol. I, Article 2(4), para. 29; R. Kolb, Ius contra bellum: Le droit international relative au maintien de la paix (2009), 247-50. This view relies on GA Res. 2625 (XXV) of 24 October I970, which states that '[e]very State likewise has the duty to refrain from the threat or use of force to violate international lines of demarcation, such as armistice lines, established by or pursuant to an international agreement to which it is a party or which it is otherwise bound to respect'. See also Eritrea/Ethiopia Claims Commission partial award, Jus ad bellum: Ethiopia's claims I-8, of I9 December 2005, para. Io, stating that the non-application of the prohibition on the use of force to a boundary dispute 'would create a large and dangerous hole in a fundamental rule of 
some support in the 2009 Tagliavini report on the Georgian-Russian war of $2008.4^{48}$ Indeed, the mere fact that an event takes place within the territorial boundaries of a state in no way precludes that this situation may be regulated by international law. 'International relations' have no specific physical locus.

To conclude, even if secession as such is in conformity with international law (or not regulated by it), the process is regulated. Use of force is prohibited, while peaceful and democratic procedures are prescribed. Any extraordinary allowance to secede has to be realized in the appropriate procedures, notably under recourse to a free and fair referendum on independence or after democratic elections, ideally under international supervision. ${ }^{49}$ The Kosovar secession process was far from perfect, but it arguably respected more or less both the prohibition of the use of force and the prescriptions of self-determination. First, the possibly unlawful use of force by NATO in its Kosovo intervention of 1999 was in terms of time and actors too remote from the declaration of independence of 2008 to count as an integral part of the independence process that could legally taint that process. Most importantly, the consent of Yugoslavia (Serbia) to Resolution I 224 and the ensuing legal framework erected a legal firewall between the prior possible violations of the prohibition on the use of force and the current secession..$^{\circ}$ Second, the declaration of independence was preceded by multiple independence referendums that had periodically been organized since I99I. Most importantly, the declaration was issued by the democratically elected representatives of the people of Kosovo, and manifested that people's will for statehood. The last elections of I 7 November 2007 were certified as having been fair and 'in compliance with international and European standards' by the UN Secretary-General. ${ }^{\text {I }}$ The secession process therefore satisfied the minimum procedural conditions of non-use of force and democratic self-determination, when a lenient standard is applied.

\section{Conclusions}

Armchair lawyers should not too readily scold the Court, which - as a composite international body - rendered a minimalist opinion on a legally complicated and politically loaded issue. The ICJ could have exercised its discretionary powers and judicial restraint and could have declined to issue an advisory opinion in this case,

international law'. However, the situation in Eritrea/Ethiopia was not identical to the case of Kovoso, because Eritrea was, at the time of the armed conflict of 1998 to which that award relates, already an independent (and recognized) state. At that time, not the existence of Eritrea as a state, but only the exact location of the boundary was controversial.

48 Independent International Fact-Finding Mission on the Conflict in Georgia, report of September 2009 ('Tagliavini-Report'), Chapter 6, at 239-4I (www.ceiig.ch/Report.html). The report relied primarily but not exclusively on contractual prohibitions of the resort to military force by the sides in the armed conflict between Georgia and Abkhazia and South Ossetia.

49 See, e.g., the Opinion No. 4 of the Badinter Commission on Bosnia-Herzegovina, which required a referendum as a precondition for recognition by the EC (repr. in (I992) 3I ILM I5OI-3). In scholarship A. Peters, Das Gebietsreferendum im Völkerrecht (I995); Tancredi, supra note 43, at I90-I. See in that sense also the written statement by Switzerland in the Kosovo proceedings, of I7 October 2008, paras. 69-80.

50 O.Corten, 'Déclarations unilaterales de l'indépendance et reconnaissances prématurées: Du Kosovoà l'Ossétie du sud et Abkhazie', (2008) I I 2 RGDIP 723, at 747-8.

5I Report of the Secretary General to the Security Council of 3 January 2008, UN Doc. S/2007/768, para. 3. 
as four judges indeed suggested in their separate or dissenting opinions. ${ }^{22}$ However, to decline to render the Opinion would have meant shying away from the judicial function entrusted to the Court by the UN Charter, and would have been a blow against current attempts to strengthen the rule of law in international relations. So, is it fair to criticize the outcome? What could have realistically happened if the Court had qualified the declaration of independence as unlawful? It would have been foolish to expect that the declaration of independence would be withdrawn as a result of a negative Advisory Opinion. In contrast, a negative answer might have inspired Serbian actors to propagate a reconquista of Kosovo with military means. Against such a spectre, the Court did not have a real choice, if it did not want to place its own legal, moral, and political authority at risk. So the answer given by the Court was to be expected. Moreover, it is, in my opinion, correct. Also, it leaves room for the argument that contemporary international law has established procedural requirements for secession, notably the non-use of military force and a democratic process. $^{53}$

However, the method by which the result was reached is less than satisfactory. It is in functional terms appropriate for a Court to give a parsimonious decision (and this applies not only to judgments, but also to advisory opinions). The Kosovo AO was not only parsimonious, but rather sophistic. The ICJ drew nitty-gritty distinctions, but failed to reflect its methodological assumptions, and did not tackle the issue of secession head-on. The Court thereby deprived its opinion of much legal relevance. ${ }^{54}$ But maybe this was the key to securing a broad acceptance among states, even among those who did not (yet) recognize Kosovo, including Serbia. ${ }^{55}$ 